\title{
ВИНИКНЕННЯ КОРУПЦЙНОГО СКЛАДНИКА В ПРОХОДЖЕННІ ДЕРЖАВНОЇ СЛУЖБИ ПІД ЧАС КАРАНТИННИХ ОБМЕЖЕНЬ В ОРГАНАХ ПЕНСІЙНОГО ФОНДУ УКРАЇНИ
}

\begin{abstract}
Досліджено основні проблеми інституту державної служби в Україні та ризики виникнення корупції. Проаналізовано стан та актуальні проблеми державної служби під час карантинних обмежень 2020 р. в Україні [11].

Розглянуто сам добір і призначення осіб на вакантні посади державної служби відповідно до Порядку здійснюється у виняткових випадках, пов'язаних із необхідністю виконання завдань $і$ функиій державних органів на період дії карантину. Такі випадки мають бути обтрунтованими. Таким чином, посади необхідні для безперебійного функиіонування державного органу (наприклад, керівники державних органів та їхні заступники, керівники самостійних структурних підрозділів та їхні заступники, а також посади відповідних спеціалістів, які вводяться у разі недоцільності утворення в державних органах окремих структурних підрозділів, для виконання окремих функиій). Відповідальність за прийняте рішення покладається на суб'єкта призначення або керівника державної служби в державному органі. Окрім того зазначаємо, щзо сфера дії Порядку з урахуванням вимог абзаиу п'ятого пункту 8 розділу II «Прикінцеві положення» Закону Украӥни «Про внесення змін до Закону України «Про Державний бюджет України на 2020 рік» поширюється на вакантні посади державної служби незалежно від того, чи оголошувався на них конкурс до набрання чинності иим Законом [12].

Ключові слова: корупиія, запобігання та протидія корупиії, державна служба, державне управління, реформування державної служби, Свропейська інтеграція, модель державної служби, публічна адміністрачія, публічна служба, діяльність на державних політичних посадах, служба в органах місиевого самоврядування, посада, посадова особа, професійна діяльність, орган державної влади.
\end{abstract}

Pinchuk Vitaliy. The occurrence of the corruption component in the civil service during quarantine restrictions in the bodies of the Pension Fund of Ukraine

The main problems of the civil service institute in Ukraine and the risks of corruption are studied. The state and current problems of the civil service during the quarantine restrictions of 2020 in Ukraine are analyzed [11].

The selection and appointment of persons to vacant civil service positions in accordance with the Procedure is carried out in exceptional cases related to the need to perform the tasks and functions of state bodies for the period of quarantine. Such cases must be justified. Thus, the positions that are necessary for the smooth functioning of the state body (for example, heads of state bodies and their deputies, heads of independent structural units and their deputies, as well as positions of relevant specialists, which are introduced in case of inexpediency of forming separate structural units in state bodies). individual functions). Responsibility for the decision rests with the appointing authority or the head of the civil service in the public body. In addition, we note that the scope of the Procedure, subject to the requirements of the fifth paragraph of paragraph 8 of Section II «Final Provisions» of the Law of Ukraine "On Amendments to the Law of Ukraine» On State Budget of Ukraine for 2020 «, applies to vacant civil service positions independently from whether a competition was announced for them before the entry into force of this Law [12].

Key words: corruption, prevention and counteraction of corruption, civil service, governance, civil service reform, European integration, model of civil service, public administration, public service, activity in state political positions, service in local self-government bodies, position, official, professional activity, body of state power.

Постановка проблеми. Країна та весь світ опинилися в умовах пандемії, спричиненої вірусом COVID-19, що призвело до необхідності запровадження суворого карантину та соціального дистанціювання. Але це не привід зупиняти реформи чи державну службу в цілому, адже від ефективності роботи публічної адміністрації залежить те, як країна долатиме кризу. 18 квітня 2020 року набув чинності Закон України «Про внесення змін до Закону України «Про Державний бюджет України на 2020 рік» [1].

Саме цим Законом тимчасово призупинені норми Закону України «Про державну службу» в частині конкурсного добору на посади державної служби. Натомість уведено процедуру тимчасового добору на посади державної служби шляхом укладання строкового контракту. Дана процедура діятиме впродовж карантину і 30 днів після його закінчення.

Це означає, що у виняткових випадках суб'єкт призначення або керівник державної служби державного органу можуть оголосити добір на ту чи іншу вакантну посаду державної служби у зв’язку 
3 гострою необхідністю забезпечення функціонування цього державного органу шляхом укладання строкового контракту $[6 ; 13]$.

Аналіз останніх досліджень і публікацій. Проблеми та методи протидії корупції досліджували зарубіжні фахівці, а саме: А. Авенаріус, В. Ананд, Г. Блек, Н. Беслі, Н. Макіавелі, М. Беккер, Г. Беккер, Л. Вайлд, Н. Вінер, Е. Кант, Ф. Луі, Сар Дж. Пундей, Л. Мизес, Дж. Муди-Стюарт, Л. Туроу, М. Олсон, С. Роуз-Аккерман, Д. Мак-Ларен, П. Чендер, Ф.Фукуяма.

Питаннями дослідження корупційних процесів займалися такі вітчизняні вчені, як: І. Білас, І. Голосніченко, О. Дудоров, М. Камлик, О. Кожушко, І. Корж, А. Красницька, В. Свтушевський, М. Мельник, Є. Невмержицький, Г. Омельченко, В. Прісняков, М. Хавронюк, С. Стеценко, Л. Скорик, О. Терещук, Б. Щур, В. Чубарєв, В. Чорновіл, К. Футей, С. Хмара та ін.

Вагомий внесок у формування основ національної антикорупційної стратегії в умовах суспільнополітичних трансформацій в Україні можна знайти у працях В. Авер'янова, В. Бакуменко, С. Дубенко, О. Кальмана, Н. Липовської, О. Маркеєва, М. Мельника, В. Мартиненко, Т. Мотренко, Н. Нижника, Є. Невмержицького, А. Новака, В. Олуйко, М. Погорецького, О. Прохоренко, С. Рогульського, С. Серьогіна, М. Стрельбицького, Р. Тучака і багатьох інших [11].

Виділення не вирішених раніше частин загальної проблеми. Інститут публічної служби (державної служби та служби в органах місцевого самоврядування) $є$ надзвичайно важливим елементом механізму урядування, відіграючи виняткову роль у функціонуванні держави, забезпеченні прав і свобод людини i громадянина. Однак на перешкоді досягненню зазначених важливих цілей стоять «слабкість» публічної служби та її нездатність ефективно протистояти корупції. Зокрема, для теперішнього стану організації та функціонування публічної служби в Україні характерними лишаються такі корупційні ризики, як непрозорий та недостатній рівень оплати праці більшості публічних службовців, надмірний суб'єктивізм у вирішенні питань публічної служби, низький професійний рівень багатьох публічних службовців.

Мета статті. Метою статті $є$ з'ясування теоретичної та нормативно-правової основи інституту державної служби в Україні разом із визначенням шляхів подолання корупції в ії̈ діяльності в період карантину шляхом добору та ефективної і швидкої адаптації державних службовців.

Виклад основного матеріалу. Визначальною процедурою відбору державних службовців $є$ конкурс. Для умов реформування державної служби під час дії карантину та ефективного й якісного виконання завдань держави законодавчо було закріплено проводити добір кадрів. Але без проведення відкритого конкурсу, який раніше проводився та ефективно зарекомендував себе, можна вважати, втрачена відкритість визначення переможця.

Тому для проведення конкурсу Порядком було визначено процедуру заміщення вакантних посад особами, які здатні виконувати свої посадові обов'язки та професійно проходити службу в органах влади.

Для належної і прозорої організації процесу конкурсного відбору на посади державної служби створено Єдиний портал вакансій державної служби НАДС, на якому особи, що бажають працювати в державних органах, можуть знайти всю необхідну інформацію про відкриті вакансії державної служби України [7; 18].

На жаль, масове скорочення працівників в органах влади, у тому числі й органах Пенсійного фонду України, та відміна норми статті граничного віку (раніше це була межа 65 років), свідчать про неякісний відбір кадрового потенціалу. За умов низького посадового окладу, який майже прирівняний до мінімальної заробітної плати, $є$ великий ризик добору кандидатів, котрі вже отримують пенсійне забезпечення (тобто пенсію), але намагаються працювати в державних органах на посадах, які не $\epsilon$ «ефективними».

А саме Постановою від 05.08.2020 № 688 КМУ вніс зміни до Постанови «Деякі питання призначення на посади державної служби на період дії карантину, установленого з метою запобігання поширенню на території України гострої респіраторної хвороби COVID-19, спричиненої коронавірусом SARS-CoV-2» від 22.04.2020 № 290 (далі - Постанова № 290; Порядок № 290) [12]. Міністерства, інші центральні органи виконавчої влади та місцеві державні адміністрації повинні у двотижневий строк після скасування карантину, установленого з метою запобігання поширенню на території України гострої респіраторної хвороби COVID-19, спричиненої коронавірусом SARS-CoV-2, оголосити конкурси на посади держслужби, на які призначали відповідно до Порядку № 290. У попередній редакції Постанови № 290 строк оголошення конкурсів становив два місяці [8; 17].

Тимчасова процедура на період дії карантину для добору на державну службу та 30 днів після його завершення укладатиметься строковий контракт. Хоча ця процедура передбачає тимчасове призначення на посади, але втрачений час для справжніх професіоналів не повернути, які б хотіли працювати на державу й ії розвиток.

Стрімке реагування на ризики та поповнення лав державних службовців розглянемо на прикладі добору в конкретних структурних підрозділах в органах Фонду. 
Так, у головного спеціаліста відділу формування електронних трудових книжок Управління інформаційних систем та електронних реєстрів величезний обсяг обов'язків:

1. Здійснювати ведення та супроводження інформаційних систем, що забезпечують опрацювання електронних трудових книжок.

2. Опрацьовувати та вносити відомості щодо трудової діяльності застрахованих осіб на підставі отриманих через вебпортал електронних послуг Пенсійного фонду України сканованих копій трудових книжок до персональної облікової картки застрахованої особи в реєстрі застрахованих осіб.

3. Перевіряти та контролювати відповідність даним системи персоніфікованого обліку внесених відомостей про трудову діяльність застрахованих осіб, виявляти випадки відсутності в трудовій книжці необхідних записів, неправильних чи неточних записів або інших розбіжностей.

4. Організовувати взаємодію із застрахованими особами та страхувальниками через електронний кабінет на вебпорталі електронних послуг Пенсійного фонду України шляхом направлення повідомлень про виявлені випадки відсутності в трудовій книжці необхідних записів або неправильних чи неточних записів про періоди роботи, або інших розбіжностей.

5. Забезпечувати дотримання законодавства щодо формування, накопичення та зберігання звітних даних реєстру застрахованих осіб, щодо електронних трудових книжок [14].

У головного спеціаліста відділу кадрового адміністрування та організаційного розвитку Управління по роботі з персоналом такі обов'язки:

1. Забезпечувати підготовку матеріалів щодо призначення на посади та звільнення.

2. Надавати консультативну допомогу з питань управління персоналом керівникам структурних підрозділів Головного управління.

3. Обчислювати стаж роботи на державній службі.

4. Організовувати складення Присяги державного службовця особою, яка вперше вступає на державну службу, оформляти документи про присвоєння відповідних рангів державним службовцям.

5. Ознайомлювати державних службовців із правилами внутрішнього службового розпорядку державного органу, посадовими інструкціями та іншими документами.

6. Оформляти і видавати державному службовцю службове посвідчення.

7. Здійснювати контроль над установленням надбавок за вислугу років.

8. Формувати графік відпусток персоналу Головного управління Фонду, готувати проєкти наказів щодо надання відпусток персоналу, контролювати їх подання та вести облік.

9. Ведення кадрового обліку в комп'ютерній програмі «АЛЬФА.БУХГАЛТЕРІЯ».

10. Здійснювати облік військовозобов'язаних і призовників та бронювання військовозобов'язаних у Головному управлінні Фонду.

11. Забезпечувати в межах своїх повноважень додержання вимог законодавства про інформацію, захист інформації з обмеженим доступом відповідно до режиму ії обробки [15].

У начальника відділу обслуговування громадян (сервісний центр) Управління обслуговування громадян Головного управління Фонду такі обов'язки:

1. Здійснювати керівництво роботи відділу щодо прийому громадян стаціонарно, на виїзних прийомах, на віддалених робочих місцях, дистанційно та шляхом надання електронних послуг, у тому числі через агентські пункти відповідно до Положення «Про організацію прийому та обслуговування осіб, які звертаються до органів Пенсійного фонду України», затвердженого Постановою правління Пенсійного фонду України від 30.07.2015 № 13-1 та зареєстрованого в Міністерстві юстиції України 18.08.2015 за № 991/27436 (зі змінами).

2. Візувати документи, що надаються начальнику Головного управління Фонду його заступникам.

3. Здійснювати моніторинг послуг, які надаються відділом, та оцінку якості обслуговування спеціалістами відділу, застосовувати заходи щодо усунення виявлених недоліків.

4. Забезпечувати в установленому порядку складання звітності з питань, віднесених до компетенції відділу.

5. Узагальнювати, аналізувати та підготовлювати керівництву Головного управління інформаційні та аналітичні матеріали з питань роботи відділу, вносити пропозиції щодо вдосконалення роботи.

6. Здійснювати контроль над своєчасною передачею сформованих пакетів документів до структурних підрозділів Головного управління, до компетенції яких належить вирішення питання.

7. Проводити інформаційно-роз'яснювальну роботу з питань пенсійного забезпечення, надавати практичну, консультативну та методичну допомогу з питань, що входять до компетенції відділу.

8. Здійснювати контроль над виконанням спеціалістами відділу своїх функцій.

9. Звітувати перед начальником Управління обслуговування громадян Головного управління про виконання покладених на відділ завдань. 
10. Приймати участь у проведенні семінарів та інших навчальних заходів із працівниками Головного управління з питань, віднесених до компетенції відділу [16].

Тому процедура добору шляхом укладання на державній службі строкового контракту повністю відрізняється від класичного відкритого конкурсу, де незалежно оцінюються професіоналізм та компетентність кандидатів, не проводиться незалежне тестування та не проходять ситуативні завдання.

Сьогодні корупція $є$ загрозою не тільки в організації добору кадрового потенціалу а й функціонуванні чесності, демократії та соціальній справедливості.

Висновки і пропозиції. Важливість дослідження даного питання полягає у тому, щоб унеможливлювати породження корупційного складника в умовах карантину під час добору на державну службу та доопрацювати Порядок і досягнення проходження «класичного» конкурсу. Контракт триватиме до проведення конкурсу, але не більше чотирьох місяців після відміни карантину. Хоча державний службовець, який працював на умовах контракту, і буде звільнений, але матиме право пройти традиційний конкурс, він вже матиме більш спеціалізовані навички та потенційно матиме перевагу перед іншими кандидатами на цю ж посаду.

Таким чином, проаналізовано можливість реалізації інноваційних методів поліпшення кадрового потенціалу та напрямів формування і функціонування високоефективної кадрової політики у державних органах влади в умовах карантинних обмежень, що дає змогу оптимізувати діяльність органів державної влади за умови підвищення якості адміністративно-управлінських процесів, що й $є$ перспективою подальших наукових досліджень у даному напрямі.

\section{Література:}

1. Про внесення змін до Закону України «Про Державний бюджет України на 2020 рік» : Закон України від 26 листопада 2020 p. № 553-IX / Верховна Рада України. URL: https://zakon.rada.gov.ua/laws/show/553-20\#Text.

2. Про державну службу : Закону України від 24 жовтня 2020 р. № 889-VIII / Верховна Рада України. URL: https://zakon.rada.gov.ua/laws/show/889-19\#Text

3. Про затвердження Порядку проведення конкурсу на зайняття посад державної служби : Постанова Кабінету Міністрів України від 14 липня 2020 р. № 246-2016-п / Верховна Рада України. URL: https://zakon.rada.gov.ua/laws/ show/246-2016-\%D0\%BF\#Text

4. Про ратифікацію Конвенції Організації Об’єднаних Націй проти корупції : Закон України 28 квітня 2020 р. № 251-V/ Верховна Рада України. URL: https://zakon.rada.gov.ua/laws/show/251-16\#Text

5. Конвенція Організації Об’єднаних Націй проти корупції від 31 жовтня 2003 р. № 995_c16 / Верховна Рада України. URL: https://zakon.rada.gov.ua/laws/card/995_c16

6. Щодо процедури тимчасового добору на державну службу на період карантину / Національне агентство України 3 питань державної служби. URL: https://nads.gov.ua/news/shchodo-proceduri-timchasovogo-doboru-na-derzhavnusluzhbu-na-period-karantinu

7. Конкурс як спосіб реалізації права на державну службу. Юридична газета. 2020. URL: https://yur-gazeta.com/ publications/practice/inshe/konkurs-yak-sposib-realizaciyi-prava-na-derzhavnu-sluzhbu.html

8. Уряд змінив умови призначення на держслужбу під час карантину. Кадровик. URL: https://www.kadrovik01.com.ua/ news/4627-uryad-zmniv-umovi-priznachennya-na-derjslujbu-pd-chas-karantinu

9. Під час карантину державних службовців добиратимуть за тимчасовою процедурою. Урядовий портал. URL: https://www.kmu.gov.ua/news/pid-chas-karantinu-derzhavnih-sluzhbovciv-dobiratimut-za-timchasovoyu-proceduroyu

10. Корупційні ризики в діяльності державних службовців / Міністерство юстиції. URL: https://minjust.gov.ua/m/str_34678

11. Інститут публічної служби в Україні та проблеми протидії корупції / Національний університет «Чернігівська політехніка» 2018 p. URL: https://pa.stu.cn.ua/tmppdf/116.pdf

12. Актуальна інформація щодо призначення на посади державної служби на період дії карантину (питання-відповіді). Портал вакансій. 2020. URL: https://career.gov.ua/site/view-article?id=35

13. Щодо процедури тимчасового добору на державну службу на період карантину. Національне агентство України 3 питань державної служби. 2020. URL: https://nads.gov.ua/news/shchodo-proceduri-timchasovogo-doboru-na-derzhavnusluzhbu-na-period-karantinu

14. Оголошення про добір / Головне управління Пенсійного фонду України в Чернігівській області. 2020. URL: https:// www.pfu.gov.ua/cn/category/diyalnist/upravlinnya-personalom/vakansiyi/

15. Основні функції структурних підрозділів головного управління Пенсійного фонду України в Луганській області / Головне управління Пенсійного фонду України в Луганській області. 2020. URL: https://www.pfu.gov.ua/ $\lg$ /122-osnovni-funktsiyi-strukturnyh-pidrozdiliv-golovnogo-upravlinnya-pensijnogo-fondu-ukrayiny-v-luganskij-oblasti/

16. Начальник відділу обслуговування громадян № 8 (сервісний центр) Управління обслуговування громадян (розташування робочого місця в м. Ічня). Портал вакансій. 2020. URL: https://career.gov.ua/site/view-vacantion?id=38890

17. Призначення на вакантні посади держслужби на період дії карантину: роз'яснення від НАДС / Приазовська районна державна адміністрація. URL: http://priazrda.gov.ua/index.php?news=1738.

18. Юридична газета: Конкурс як спосіб реалізації права на державну службу / Сьомий апеляційний адміністративний суд. URL: https://7aac.gov.ua/en/yuridichna-gazeta-konkurs-yak-sposib-realizaci\%d1\%97-prava-na-derzhavnu-sluzhbu/ 